DARIUSZ BĘBEN

Instytut Filozofii

Forum Pedagogiczne

Uniwersytet Śląski

9 (2019) 2, cz. 2

Wpłynęło: 15.04.2019

Katowice

ORCID ID: https://orcid.org/oooo-ooo1-9829-6222

Zatwierdzono do druku: 20.11.2019

DOI: 10.21697/fp.2019.2.30

\title{
SOKRATES JAKO WYCHOWAWCA. SOKRATEJSKIE ROZMYŚLANIA JANA PATOČKI ${ }^{1}$
}

\author{
„Właściwie Sokrates \\ był palony \\ był przesłuchiwany \\ strzelano doń jak do zwierzęcia, \\ był przybity do wrót, \\ był zadeptywany \\ Wczoraj widziałem \\ Sokratesa \\ Rozmawiał na agorze \\ Śmiał się cicho"
}

(Holub 1969, s. 119).

Streszczenie: Przedmiotem analizy jest rola Sokratesa jako wychowawcy w ujęciu czeskiego fenomenologa Jana Patočki. Operując ontologicznymi kategoriami ruchu i wstrząsu, próbuje on zbudować filozofią wychowania. Punktem wyjścia jest Sokratejskie pytanie, którego celem jest uświadomienie sobie niepewności i problematyczności świata. Taki negatywny aspekt filozofowania (wychowania) pozwala jednak wznieść się ku transcendencji, w poczuciu, że przekraczając świat, stajemy się sobą samym.

Słowa kluczowe: Patočka; Sokrates; wychowanie; dusza; ruch.

\section{Wstęp}

Jan Patočka, o którego części recepcji Sokratesa będzie tutaj mowa, uważał, że ateński mędrzec oraz tragiczna i wielce symboliczna śmierć nie bez powodu stały się przedmiotem filozofii. Czeski filozof idzie jeszcze dalej: „Nie jest możliwe

1 Artykuł powstał w ramach projektu badawczego NCN, nr 2011/o3/b/hs1/o17oo pt. „Człowiek w horyzoncie dziejów i autentyczności bycia. Studia z filozofii Jana Patočki”. 
filozofowanie bez Sokratesa" (Patočka 1999, s. 224). Filozofia Ateńczyka, przeciwstawiająca się temu, co absolutne, oczywiste i niezmienne w filozofii, ukazała nowe możliwości życia i samego filozofowania. Pytanie o Sokratesa jest zatem pytaniem o istotę filozofii. Całą powagę i znaczenie Sokratesa w intelektualnych dziejach świata oddaje słowo „autorytet”, użyte w tytule słynnej książki Karla Jaspersa (2000).

Celem artykułu jest ukazanie jednego z obrazów Sokratesa, który stworzył Patočka. Chodzi mianowicie o Sokratesa jako wychowawcę, szczególnego typu wychowawcę. Sokrates nie jest - wbrew zdecydowanemu stwierdzeniu Arystotelesa - filozofem „pojęć i definicji”, nie proponuje określonej definicji wychowania. Chodzi mu raczej o pewien ontologiczny wymiar wychowania, który, oparty na koncepcji egzystencjalnych ruchów, wymyka się raczej pojęciowemu schematowi. W artykule zamierzam ukazać Sokratesa Patočki jako „budziciela”, jako tego, który pobudza do odwagi, żeby żyć, żeby rozporządzać gotowością do podejmowania decyzji - bycia odpowiedzialnym. Oczywiście, narzuca się pytanie: dlaczego ludzie mieliby nie chcieć żyć? Żeby na nie odpowiedzieć, trzeba uwzględnić kontekst nie tylko zapytywania Sokratesa (kryzys demokracji ateńskiej), lecz również trudnych czasów, w których przyszło żyć i filozofować Patočce.

\section{Sokrates jako przedmiot filozofowania}

O Sokratesie napisano już niemal wszystko. Trzeba sokratejskiej odwagi, aby poświęcić mu kolejne strony analiz. Pisano o Ateńczyku apologetycznie i krytycznie. Pełnił rolę protofilozofa, sofisty, agnostyka, pragmatyka, kapłana, bramina, retora czy décadent. To pewnie nie wszystko, o ile w ogóle istniał ktoś zwany Sokratesem (w zasadzie nie ma to żadnego znaczenia, chodzi bowiem o ducha jego filozofii). Jednak trudno wyobrazić sobie filozofię bez Sokratesa.

Obraz Sokratesa nie jest jednoznaczny. Bezpośredni świadkowie - Ksenofont, Platon i Arystofanes, a także w pewnym sensie również Arystoteles - „wzbogacili” swoimi poglądami filozoficznymi spuściznę myślową Ateńczyka. Wielkie filozoficzne interpretacje Kierkegaarda, Hegla i Nieztschego zacnie wykorzystały filozofię Sokratesa dla swoich celów. Nie dziwi więc, że niezliczeni filologowie i historycy filozofii - począwszy od Asta, a skończywszy na Zellerze - poszukiwali „autentycznego Sokratesa”.

Na szczęście o Sokratesie można mówić także krytycznie. Słusznym może być zarzut, że Sokrates rozmawia głównie sam ze sobą, że dialog jest tylko pozorem. Słuszne wydają się także uwagi dotyczące „przemocy”, którą stosował wobec swoich młodszych rozmówców (Eutyfron). Nie można zaprzeczyć, że jednym z wychowanków Sokratesa był kontrowersyjny polityk i wódz Alkibiades. Pozostaje jeszcze jego słynny intelektualizm etyczny, którego założenia krytycznie przepracował już Arystoteles. Słabość myśli Sokratesa jest tu wyraźnie widoczna. W każdym razie, jak pisał Patočka, sąd nad Sokratesem trwa do dziś. „Sokrates jako postawa 
nieustannie nieuchwytna oraz Sokrates jako potrzeba i zachęta wciąż się ponawiająca; Sokrates, którego wciąż niedoskonale konstruujemy, Sokrates, z którym lub przeciw któremu walczymy, który wbrew wszystkim czysto obiektywnych trudności jest jakoś tutaj” (Patočka 1991, s. 13).

Poważne zainteresowanie Patočki myślą grecką rozpoczyna się dopiero po wojnie, gdy nie mógł zajmować się fenomenologią jako „filozofią burżuazyjną”. Sokrates zajął szczególne miejsce w twórczości Czecha, do tego stopnia, że zainteresowania naukowe starożytną filozofią grecką stanowić będą drugi, obok fenomenologii, punkt oparcia jego filozofowania (Pauza 1997). Oba te pola - fenomenologia i starożytność grecka - wzajemnie będą się uzupełniać, co można dostrzec w ostatnim dziele Patočki, a mianowicie Esejach heretyckich z filozofii dziejów. Pisze w nich m.in.: „Wśród interpretacji całej plejady filozofów: od filozofii antycznej aż po czasy współczesne znajdziemy tego jednego, który odgrywa kluczową rolę dla zrozumienia jego filozoficznej pozycji, a mianowicie - Sokratesa” (Palouš 1990, s. 47).

Zdaniem Patočki, Sokrates nie był twórcą humanizmu, nie był też żadnym moralistą, którego dialektyka prowadziła do poznania cnoty. Takiego Sokratesa Patočka nie znał. Rozważał on Sokratejskie myślenie z perspektywy metafizyki. Patočka, wracając do początków nie tylko metafizyki, lecz i całej filozofii, ulega urokowi mitu źródeł, opowieści o ziemi obiecanej, której odkrycie rozwiąże wszystkie tajemnice i zagadki naszego bycia w świecie. Nie tylko utożsamiał Sokratesa z początkiem filozofii, lecz także - co ukazuje ostatni etap rozwoju myśli Czecha - z powstaniem dziejów Europy jako manifestacji sokratejskiej troski o duszę (Cajthaml 2010).

\section{Negatywny platonizm}

Drogę prowadzącą do wspomnianej powyżej ziemi obiecanej można przybliżyć w formie negatywnej. Załóżmy, że Sokrates stawia jedynie pytania, na które odpowiadają Platon i Arystoteles. Ich odpowiedzi, choć różnią się mniej lub bardziej, to jednak przedstawiają pewną pozytywną wizję całości świata, czyli metafizykę. I tak, Platon, odpowiadając na pytania Sokratesa, wkracza w świat transcendentnych idei, świat tego, co niezmienne i uniwersalne, którym rządzą pozytywne relacje (Evink 2011). Jednak ostatecznym urzeczywistnieniem (odpowiedzią) metafizyki nie była filozofia Platona, lecz Arystotelesa. Ten ostatni nie tylko doprowadził do pełni projekt swego nauczyciela, przekształcając realność ponadfizyczną w transcendentne bóstwo, lecz nadał jej również charakter naukowy, tzn. metodyczny. Tym samym metafizyka przeobraziła się w teologię, wiedzę o absolutnej, obiektywnej i pozytywnej całości. Z tej drogi - jak pokazuje historia filozofii - nie było już odwrotu. Na dłuższą lub krótszą metę można było tylko wyczekiwać momentu, gdy nastąpi katastrofa myślenia ontoteologicznego. Patočka (2015), inspirując się Sokratesem (ale także Husserlem i Heideggerem), postuluje nową formę wiedzy o absolutnym transcendowaniu, nowy stosunek do tego, co nieistniejące, a w konsekwencji człowieka do świata jako całości. 
Celem Sokratesa nigdy nie było orientowanie się ku jakiemuś wyższemu, transcendentnemu światu, lecz przeciwnie - zachwianie świata niezmiennych prawd. Podobnie postrzegał to Kierkegaard (1999, s. 41): „Każda filozofia, która zaczyna się od jakiegoś założenia, kończy się naturalnie na tym samym założeniu. Filozofia Sokratesa zaczęła się od założenia, że nic nie wie, i doszła do konkluzji, że człowiek w ogóle nic nie wie; platońska [filozofia - dop. D. B.] zaczęła od założenia bezpośredniej jedności myśli i bytu i pozostała przy tym do końca”. W tym sensie Sokrates jest ontologiem, filozofem przedmetafizycznym.

Warto tu wspomnieć apokryf Ezdrasza, który opowiada o tym, jak król Dariusz zorganizował konkurs: kto ma najsilniejszą władzę? Odpowiedzi były trzy, w kolejności: wino, król, kobiety. Dopiero Zorobabel powiedział, że żadna z tych rzeczy, ponieważ to, co jest - jest zawsze nieprawdziwe. Prawda nie jest żadnym bytem. Inaczej niż dla Greków, gdzie prawda jest zawsze podporządkowana temu, co istnieje. W chrześcijaństwie to Bóg, Pan rzeczy, nie jest żadną rzeczą, żadnym bytem. Jest „wywyższony ponad niebiosa”. Ladislav Hejdánek (1990), uczeń Patočki, zauważa, że przyczyna wyższości prawdy polega na jej niebycie, to, że nie jest ona żadnym bytem, lecz podstawą dla bytu. I w tym sensie, choć nie musi zatriumfować od razu, prawda zwycięży na wieki. Taka interpretacja pozwala odwołać się do pojęcia prawdy, nie wpadając przy tym w jej uniwersalne i absolutyzujące sidła. Tego właśnie chciał Patočka uniknąć. Prawda bowiem ukazuje, że przedmiotowość nie jest nigdy skończoną całością. Jego zdaniem, nie istnieją żadne absolutne wartości, nie jest dany żaden zbiór reguł naszego zachowania. Można go wytworzyć dopiero $\mathrm{w}$ walce $\mathrm{z}$ tym, co obecne, stając twarzą w twarz przed skończonym byciem.

\section{Sokratejskie pytanie}

Przejdźmy teraz do Sokratejskiego zapytania. Powtórzmy to jeszcze raz: Sokrates pozostaje na poziomie pytania, mówiąc językiem Heideggera - przebywa w pytaniu. Pytający sam niejako staje pod znakiem zapytania. Ale pytanie jest tylko drogą, poszukiwaniem sensu w procesie poszukiwania. Abstrahując od tematów rozmów podejmowanych przez Sokratesa z jego rozmówcami, interesujące są przede wszystkim reakcje tych ostatnich na pytania filozofa. Moment uchwycenie przez nich negatywności wynikającej z tych pytań, uświadomienie sobie, że w zasadzie nie można na nie odpowiedzieć, że jedyne, co pozostało, to tylko Nic. Spójrzmy na jeden z wielu przykładów. Oto słynne słowa Menona: „Zanim samego ciebie poznałem, słyszałem o tobie, że ty sam tkwisz w niepewności i również innych w nią wprawiasz (gmatwasz). A teraz również na mnie rzucasz czar, tak że jestem mocno zakłopotany. I wydajesz mi się, jeśli wolno mi zażartować, całkiem podobny do owej ryby morskiej, węgorza elektrycznego; mówi się bowiem o nim, że działa w sposób odurzający na tych, którzy się do niego zbliżają i dotykają. W ten właśnie sposób mnie zaczarowałaś; stałem się bowiem odurzony na ciele i duszy i nie wiem już, co ci odpowiedzieć, chociaż odbyłem już dziesięć tysięcy razy tyle rozmów z tak 
wieloma ludźmi i, jak mi się wydawało, moje racje dotyczące cnoty były dobre. Ale teraz zupełnie już nie wiem, co mam powiedzieć” (Platon 1999, 80 B).

Przeżycie tego młodego sofisty nie było wyjątkowe. Sokratejskie pytania doprowadzały jego rozmówców do odurzenia, wstydu, drętwienia, poczucia negatywności. Można nazwać stan ten również nawróceniem, przebudzeniem, uczuciem pustki, produktywną negatywnością itp. Odpowiedź: „Na Zeusa, nie”, odsłania proces wstrząsu, aby użyć celnego zwrotu Patočki. To egzystencjalne nastawienie oznacza zachwianie wiary w to, co absolutne i oczywiste, sproblematyzowanie sensu. Filozofia to właśnie akt problematyzowania. Filozofia pojawia się wraz z rumieńcem wstydu, odsłaniając nowy wymiar życia, pozwalający zrozumieć ciemną rzeczywistość, w której musimy jednak żyć. Człowiek w świecie nie pozostaje jednak z niczym. Doświadczenie nieoczywistości jest tragiczne, jednak różni się od Beckettowskiej nicości, rozpaczliwego odwrócenia się plecami do świata. Sokratesowi chodzi o ontologiczną niepewności egzystencji. Patočka (1998, s. 93) pisze na ten temat następująco: „Człowiek nie może żyć bez sensu, i to sensu całkowitego i absolutnego. To znaczy: nie może żyć w pewności braku sensu. Ale czy znaczy to, że nie może żyć w sensie poszukiwanym i problematycznym?”.

Pozostaje jeszcze społeczno-polityczny kontekst sokratejskiego pytania. Czy jest on ważny? Tak, ponieważ pytanie mogło pojawić się wówczas, kiedy Sokrates „siedział miastu na karku”. Pytanie nie tyle pojawia się w polis, ile je kształtuje. Polis, podobnie jak filozofia, wykiełkuje z mitu. Bycie-w-polis umożliwiło postawienia znaku zapytania przed tym, co absolutne - także przed śmiercią (Patočka 1996b, s. 98).

Pytania Sokratesa nigdy nie są zawieszone w filozoficznej próżni. Nie są retoryczne. Można powiedzieć, że dotyczą tego, co moralne. Sokratejskie arcypytanie brzmi: czym jest dobro? Co może stanowić powszechny cel życia człowieka? Na te pytanie Sokrates nie znajduje jednak odpowiedzi. Sokrates nie operuje żadną definicją dobra. Wiedza o dobru to wiedza o jego niewiedzy. Innymi słowy: pytanie o dobro stanowi miarę pierwotnego stanu niewiedzy. Przypomnę, że w tle pytania stoi dziejowe bycie człowieka, a nie królestwo wiecznych idei (Patočka 1996c, s. 139 i nast.). Możliwe jest zatem tylko życie w bliskości dobra.

Potrafimy jednak przeciwstawić dobro złu. Dlaczego? Dusza jest tym, dzięki czemu możemy rozróżnić między dobrem a złem, prawdą a fałszem. Dusza wewnętrznie kształtuje człowieka, staje się nosicielką jego losu. Patočka (1999, s. 226) mówił w tym przypadku o otwartości duszy (od razu narzuca się porównanie z Komeńskim), która w istotny sposób wiąże się z życiem odpowiedzialnym. Jest to idea obca filozofii greckiej, jednak można powiedzieć, że odpowiedź Sokratesa brzmi: troszcz się o duszę, a zatem bądź odpowiedzialny za siebie i za innych. Tylko ty możesz to zrobić. Tylko ty, nie wiedząc, czym jest dobro, dzięki duszy możesz ku niemu się ukierunkować. Tylko ty możesz pokonać ową nicość, negatywność, niepewności oraz nadać swemu życiu sens. W jednej z rozpraw zawartych w Esejach heretyckich z filozofii dziejów Patočka (1998, s. 91) pisze: „To, że filozofia nie potrafi 
dać człowiekowi wyższego sensu życia, całkowicie pozytywnego, niezłomnego, zrozumiałego wprost, bez żadnej zagadkowości, do jakiej prowadzi zachwianie pierwotnej skromnej sensowności, to, że metafizyka, zamiast do obiecywanej czy oczekiwanej sytuacji pozytywnej, wiedzie do niepewności, jest doświadczeniem występującym z wielką siłą właśnie wtedy, gdy człowiek, pozbawiony praktycznego sensu swej egzystencji w społeczności, zwraca się ku wewnątrz, aby tam znaleźć to, czego mu życie w społeczności - a więc również w kosmosie, którego społeczność jest częścią i odbiciem - odmówiło”.

\section{Wychowanie jako ruch}

Zdaniem Patočki, Sokratejskie pytanie jest urzeczywistnieniem egzystencjalnego ruchu, procesu zachodzącego wewnątrz człowieka, związanego z odrzuceniem naiwnej i ograniczonej codzienności, z podniesieniem się z upadku. Czeski fenomenolog wyróżnia trzy takie ruchy. Życie człowieka rozpoczyna się od zakorzeniania w tym, co dane. Akceptujemy wszystko to, co nas otacza. Stajemy się częścią świata naturalnego. Czujemy się bezpiecznie, czujemy się jak w domu. Ruch ten stanowi podstawę naszego przetrwania, wyznaczając ramy naszej cielesnej egzystencji w panowaniu nad światem. Świat taki przedstawia Homer, w którym wszystko jest określone przez boskie prawo, któremu człowiek, jeśli chce przetrwać, musi się podporządkować.

Jednak człowiek posiada zdolność wyrwania się z tego ciemnego świata instynktów. Otwiera się przed człowiekiem droga do tego, co dane w pełnej jasności. Drugi ruch samorealizacji (obrony) jest już ruchem troski o rzeczy, które nas opanowują, które sprawiają, że jesteśmy dla siebie obcy. Panując na rzeczami, sami stajemy się użyteczni. Ruch drugi określa naszą teraźniejszość, wyznacza społeczny wymiar życia człowieka, w którym najważniejszym zadaniem jest praca.

Trzeci ruch życia prowadzi do prawdy, która jest dla człowieka właściwym samozrozumieniem. W tym ruchu przełomu chodzi już o autentyczną egzystencję. Tutaj odsłania się przed człowiekiem relacja zarówno do własnego życia, jak również do bytu w całości. Dopiero w tym nastawieniu człowiek może zrzec się swoich zainteresowań. Człowiek może otworzyć się na to, co nadejdzie. Ten ruch wiąże się z powstaniem filozofii i początkami człowieka dziejowego (Patočka 2009). Tak oto dzięki sokratejskiemu pytaniu i braku odpowiedzi (wstrząsowi) nastąpiło przejście od mitu do filozofii i polis, z epoki przeddziejowej do historii.

Rozważmy teraz ten sam problem od strony filozofii wychowania. Jeżeli filozofia jest nauką o naturze spekulatywnej (można z tym dyskutować), to pojawia się pytanie o jej znaczenie dla wychowania. Wydaje się, że filozofia niczego nie może zaoferować procesowi wychowania. Patočka (1996a, s. 364) pyta: „Czy takie spekulatywne myślenie może wesprzeć realny społeczny proces jakim jest wychowanie?”. Czy Sokrates w swoich rozmowach spekulował? Jeżeli założymy, że istotą jego filozofii było pytanie, to nie można mówić, że wychodził poza obszar theoria. 
Dopiero odpowiedź przynosi rozwiązanie praktyczne, dopiero odpowiedź sprawia, że wkraczamy w świat działania.

Człowiek żyje w świecie naturalnym w poczuciu pełnej harmonii. Jego przeżywające życie nie wymaga żadnych pytań. Zdarza się jednak, że coś zakłóca ową harmonię. Patočka się zastanawia, czy początkiem takiej amplitudy może być proces wychowania. Pisze on: „Pewność źródłowego świata naturalnego musi być w pewien sposób zachwiana, zaprzeczona. Wówczas człowiek doświadcza czegoś nowego, doświadcza szczególnego ruchu, który się w nim wydarza, wszystko nabiera nowego sensu, świat otwiera w szerokich horyzontach, w których dotąd się nie zjawiał. Coś takiego, faktyczne przełamanie codzienności, tępej normalności, stanowi punkt wyjścia procesu wychowania, które europejskiemu człowieczeństwu nadaje w historii sens" (Patočka 1996a, s. 367).

Wychowanie jest ruchem, procesem dokonującym się we wnętrzu człowieka. Proces ten polega w swojej istocie na odejściu od naiwnej codzienności. Człowiek poruszony staje się innym człowiekiem. Wychowanie to wstrząs, choć nie zawsze musi on mieć za źródło filozofii. Może to być na przykład wstrząs religijny, estetyczny itd. Wydaje się jednak wątpliwe, żeby mógł on zostać wywołany przez naukę. Nauka nie jest drogą via negationis.

Filozof interpretuje świat, ponieważ nie ma innego życia niż życie w świecie. Świat i życie podlegają interpretacji - to jest właśnie zadaniem filozofii. Interpretacja pojawia się zawsze tam, gdzie coś jest niepewne, niedookreślone, gdzie coś wymaga rozjaśnienia. Pedagogika powstaje tam, gdzie proces wychowania staje się nieoczywisty, gdzie wychowanie staje się problemem (Patočka 1996a, s. 400). Jak twierdzi David Rybák (2017), Patočka jest świadom, że wychowanie to proces, dokonujący się w naturalnym nastawieniu, w dużej mierze nieuświadomiony. Wychowanie to po prostu kształtowanie ludzkich zdolności do bycia istotą społeczną, która posiada możliwość przenoszenia dalej pewnych treści wypracowanych przez pokolenia. Jednak najważniejszym elementem w wychowaniu jest kształtowanie samego siebie. Pedagogika musi zatem zakładać ideę sensu życia. To właśnie filozof - jak zaznacza Patočka - oferuje klucz do owego sensu.

Trzeba dodać, że pojęcie Bildung jest szersze niż czeskie „wychowanie”. Patočka proponuje termin formacja, ona bowiem rozgrywa się w wielu warstwach zmieniającej się świadomości (Czech przywołuje tu pojęcie aktualizacji Theodora Litta). Sytuacja pedagogiczna musi zawierać wszelkie stanowiska: wychowawcy i wychowanka oraz wszelkie impulsy (obiektywny, subiektywny i społeczny). Zadaniem sokratejskiego elenchos jest rozpoznanie egzystencjalnego stanu duszy. Nie chodzi w nim o to, co powszechnie rozumiemy przez metodę sokratejską, która za pomocą elenktyki i majeutyki pomaga wydobyć z rozmówcy wiedzę, lecz o egzystencjalną pomoc w odkryciu nowej zasadniczej możliwości własnego bycia.

Człowiek nie jest określonym z góry bytem. Przeciwnie - człowiek (uczeń) nadaje sens rzeczom (światu), widzi je ze stanowiska swych możliwości. Uczeń musi poszukiwać swej drogi. Zadaniem wychowawcy jest udzielenie mu pomocy. 
Zawsze jest to sytuacja konfliktowa. Nie ma bowiem równości między wychowawcą a wychowankiem. Ten drugi musi się podporządkować autorytetowi tego pierwszego. Mimo że wychowanek sam decyduje o własnym życiu, to jednak czuje, że nie jest w pełni niezależny. Proces wychowania przypomina walkę (gr. agon). Walkę, w której uczeń, realizując swoją wolność, przezwycięża nauczyciela. Przypomnę, że Sokrates został skazany na śmierć także za deprawowanie młodzieży. Co kryje się za tym zarzutem? Odpowiada Hegel (1994, s, 604): „Sprowadzanie na złą drogę młodzieży polegało na tym, że to, co bezpośrednio obowiązywało, stawało się chwiejnym".

\section{Zakończenie}

Przesłanie Sokratesa skierowane do jego uczniów można streścić słowami: „Miejcie odwagę żyć dobrze!”. Tą właśnie zasadą kierował się Patočka, gdy podpisywał i autoryzował swoją osobą Kartę 77. Na frontonie świątyni Appolina w Delfach wyryto napis: „Poznaj samego siebie”. Ta maksyma często towarzyszy rozmowom Sokratesa. Nie chodzi tu o żadne wewnętrzne poznanie, lecz o dramat duszy, która poznając siebie, uzmysławia sobie również własne ograniczenia, a w dalszej kolejności jest w stanie uznać swoją skończoność i bezsilność. Wychowanek musi uporać się ze swoim życiem sam, mimo że śpieszy mu z pomocą wychowawca (Sokrates). Oto właściwy sens egzystencji. Ludzkie życie będzie zawsze dążyć do życia w całości, która jednak nigdy nie jest człowiekowi dana. Dusza jako miejsce pytania o sens czyni nas odpowiedzialnymi za świat, ale także za Innego, za wychowanka. W tym kontekście paideia to nie tylko troska o duszę, lecz również a może najpierw i przede wszystkim - jej „przebudzenie”. Jeśli dokona się owo przebudzenie, to człowiek będzie mógł wznieść się ponad bezsens życia i rozpocząć proces kształcenia, którego celem jest nadanie sensu nie tylko swojemu życiu, lecz także całej kulturze europejskiej. I dlatego, zdaniem Patočki (1998, s. 103): „,Sokrates jest filozofem, jeśli nie największym, to najprawdziwszym”.

\section{Bibliografia}

Cajthaml M. (2010). Evropa a péče o duši. Patočkovo pojetí duchovních základů Evropy. Praha: Oikúmené.

Evink E. (2011). The Relevance of Patočka's „Negative Platonism”. W: Abrams E., Chvatík I. (red.). Jan Patočka and the Heritage of Phenomenology. Centenary Papers. Dordrecht-Heidelberg-London-New York: Springer, s. 57-71.

Hegel G.W.F. (1994). Wykłady z historii filozofii, t. 1. Nowicki Ś. F. (tłum.). Warszawa: PWN.

Hejdánek L. (1990). Pojetí pravdy a jeho meontologické předpoklady. „Reflexe”, 1, S. 1-11.

Holub M. (1969). Model człowieka, tłum. Pleśniarowicz J. Warszawa: PIW. 
Jaspers K. (200o). Autorytety. Sokrates, Budda, Konfucjusz, Jezus. Bentkowski P., Flaszak R. (tłum.). Warszawa: Wydawnictwo KR.

Kierkegaard S. (1999). O pojęciu ironii z nieustajacym odniesieniem do Sokratesa. Djakowska A. (tłum.). Warszawa: Wydawnictwo KR.

Pauza M. (1997). Patočkưv Sókratés. „Filosofický časopis”, 1 (45), s. 899-908.

Palouš M. (1990). Filosofovat se Sokratem. „Filosofický časopis”, 1-2 (38), s. 45-58.

Patočka J. (1991). Sókratés. Přednášky z antické filosofie. Praha: SPN.

Patočka J. (1996a). Filosofie vychovy. W: tenże: Péče o duši. Sv. 1. I. Chvatík I., Kouba P. (oprac.). Praha: Oikúmené, s. 363-440.

Patočka J. (1996b). Kapitoly ze současné filosofie. W: tenże: Péče o duši. Sv. 1. Chvatík I., Kouba P. (oprac.). Praha: Oikúmené, s. 85-100.

Patočka J. (1996c). Věčnost a dějinnost. Rádlův poměr k pojetím člověka $v$ minulosti a současnosti. W: tenże: Péče o duši. Sv. 1. Chvatík I., Kouba P. (oprac.). Praha: Oikúmené, s. 139-242.

Patočka J. (1998). Czy dzieje maja sens? Zychowicz J. (tłum.). W: tenże, Eseje heretyckie z filozofii dziejów. Czcibor-Piotrowski A., Szczepańska E., Zychowicz J. (tłum.). Kraków: Znak, s. 73-106.

Patočka J. (1999). Platón a Evropa. W: tenże, Péče o duši. Sv. 2. Chvatík I., Kouba P. (oprac.). Praha: Oikúmené, s. 149-355.

Platon (1999). Menon. Witwicki W. (tłum.). W: tenże, Dialogi, t. 1. Kęty: Antyk, S. $459-503$.

Patočka J. (2009). „Přirozený svět” v meditaci svého autora po třiatřiceti letech. W: tenże, Fenomenologické spisy. Sv. 2. Chvatík I., Frei J. (oprac.). Praha: Oikúmené, s. $265-334$.

Patočka J. (2015) Negatywny platonizm. O genezie, problematyce i zaniku metafizyki oraz pytaniu, czy filozofia może istnieć bez niej. Borys M. (tłum.). „Kwartalnik Filozoficzny", t. XLIII, z. 4, s. 167-204.

Rybák D. (2017). The Educational Aspect of Phenomenological Reduction. „Kultura i Wychowanie", 7, s. 42-50.

\title{
SOCRATES AS AN EDUCATOR: SOCRATIC DELIBERATIONS BY JAN PATOČKA
}

\begin{abstract}
The article focuses on the role of Socrates as an educator in the view of the Czech phenomenologist Jan Patočka. Philosophy of education consists of exposition of the particular ontological categories (movement and shock). The starting point is the Socratic question that lets us realize the uncertainty and problematics of the world. However, this negative aspect of philosophizing allows us to rise beyond transcendence, we cross the world to become ourselves.
\end{abstract}

Keywords: Patočka; Socrates; education; spirit; movement. 
Dariusz Bęben - doktor habilitowany, adiunkt w Instytucie Filozofii Uniwersytetu Śląskiego. W swoich badaniach koncentruje się na filozofii czeskiej i słowackiej, historii ruchu fenomenologicznego w Polsce i na świecie. Ważniejsze publikacje: Polska fenomenologia przedwojenna. Antologia tekstów (współredaktor, Katowice 2013); Człowiek $w$ horyzoncie dziejów i egzystencji bycia. Studia z filozofii Jana Patočki (Katowice 2016). Adres korespondencyjny: ul. Bankowa 11, 40-007 Katowice. Adres e-mailowy: dariusz. beben@us.edu.pl. 